UDC 811.133.1'1:7.037'19"

https://doi.org/10.18485/ms_zmss.2020.97.6

Vladimir V. Feshchenko

Institute of Linguistics

Russian Academy of Sciences

vladimirfeshchenko@iling-ran.ru

\title{
THE PERFORMATIVE TURN IN PHILOSOPHY AND VERBAL ART: MOSCOW CONCEPTUALISM'S LINGUISTIC (NON-?)CREATIVITY ${ }^{1}$
}

The performative turn, which manifested itself in the 1960-70s, followed the linguistic turn, exposing a tendency towards putting language in action. The article outlines the implications of the performative approach in the field of artistic discourse and, more precisely, the discourse of verbal art and discusses Moscow conceptualism as a poetic manifestation of performativity. In the Soviet Union and countries of the Eastern bloc, conceptualism manifested itself in the deideologization of the official language of power. Ordinary utterances invaded the poetic texts and canvases, opposing the official discourse of Soviet authorities. The study of verbal artworks by I. Kabakov, L. Rubinstein, D. A. Prigov and A. Monastyrsky elucidates the dialectics of performativity and (non-) creativity in the case of verbal utterances used in poetic discourse.

Key words: performance, linguistic creativity, verbal art, Moscow Conceptualism.

У нас, в России, в смысле, все просто. У нас перформанс он и есть перформанс. <..> Нечто самодостаточное, замкнутое и немного загадочное. <..> У них же и театр - перформанс, и шоу - перформанс, и всякое вы*бывание - тоже перформанс. $<$...> Нет, у нас резче, определеннее, монументальнее и сакральнее как бы. Да и само слово «перформанс» звучит для русского уха, склонного к разгадыванию всяческих внутренних значений, тайных заговоров и энигм, как: пер-фор, манн-с! То есть, а ну-ка покажи себя, человек-с!

Д. А. Пригов

The purpose of this article is to elucidate the dialectics of performativity and (non)creativity in the case of verbal utterances used in poetic discourse. A prerequisite for this consideration is the so-called performative turn, which

1 The research is funded by grant № 19-18-00040 of the Russian Science Foundation and is carried out at the Institute of Linguistics, Russian Academy of Sciences. 
manifested itself in the 1960-70s following the linguistic turn in philosophy and exposing a tendency towards putting language in action. The performative turn in culture is based on the understanding of language utterance as an action that changes the circumstances of the world and communication. In a wider cultural perspective, this turn manifested itself in various conceptions and theories of action (ritual, performance etc.) ${ }^{2}$. In the foreground of the performative turn are, as the cultural scholar D. Bachman-Medick summarizes, "not the cultural semantic interconnections and not the idea of "culture as a text", but the practical dimension of the production of cultural meanings and experience" (Бахман-Медик 2017: 122).

What are the implications of the performative approach in the field of artistic discourse and, more precisely, the discourse of verbal art ${ }^{3}$ ?

The origins of the performative turn lie mainly in the sphere of analytical philosophy of language. The most important role in this breakthrough was played by the philosophical studies of L. Wittgenstein, especially of his late period. The notion of language as a "life form" realized in diverse "language games" challenged F. de Saussure's static view of language as a system. The Austrian philosopher himself was a passionate admirer of art and classical literature. However, surprisingly, we do not find any significant comments or thoughts regarding the language of art or literature in his writings (apart from discussions of psychological aesthetics in general). However, Wittgenstein's linguophilosophical ideas contributed significantly to artistic practices. The publication of his Philosophical Investigations in 1953 gave rise to a whole movement in art called "conceptualism".

Just as in the case of Wittgenstein, we do not observe any considerations about the nature of poetic utterance in writings of another founder of linguistic pragmatics, J. Austin. Introducing his classification of "performatives", he specifically stipulated that the "poetic use of language" cannot be illocutionary. Moreover, Austin seems to even chuckle at attempts to interpret a poetic utterance in terms of linguistic philosophy. Analyzing the phrase "Go and catch a falling star" from John Donne's poem, he wonders how it is possible to carry out such an action, as to "catch a falling star". In a derogative manner, he comments: "There are parasitic uses of language, which are 'not serious', not the 'full normal use'. The normal conditions of reference may be suspended, or no attempt made at a standard perlocutionary act, no attempt to make you ' do anything, as Walt Whitman does not seriously incite the eagle of liberty to soar" (Austin 1962: 104). At this point, Austin's reflection on poetry terminates. However, after several decades, his theory inspired scholars to study speech acts in literature (Culler 2000; Hillis Miller 2001).

2 See, e.g., the now classical study (Fischer-Lichte 2008).

3 The term "verbal art" is used here in R. Jakobson's sense, as any aesthetic form of linguistic activity. The same meaning is maintained in the pioneering work on performativity in verbal art (Bauman 1984). 
The notion of discourse introduced by E. Benveniste and Z. Harris and later developed by M. Foucault, Th. Van Dijk, and others served as a decisive moment of the performative turn. It was introduced exactly in connection with performativity with reference to Austin's publications in the early 1950s, as a transfer of philosophical ideas into the field of linguistics. In the same 1950s, Benveniste was developing his theory of poetic discourse, claiming that "a poem is a special statement. It forms a unique discourse consisting of words connected within it for the first and only time" (cited in Laplantine 2008: 272). A poetic utterance, Benveniste clarifies, is a completely different type of utterance than an ordinary utterance. It consists of a "verbalized emotion" and "does not refer to anything but itself" (Idem: 11). His other idea relevant for our discussion is the treatment of poetic utterance as an "action". Poetic language, he writes, "is not aimed at speaking (dire), but at doing (faire)." It "pursues the goal of producing an impact, emotional or aesthetic" (Idem: 184). In these considerations we are witnessing the emergence of poetic pragmatics as a special area of linguistic research.

Concurrently with philosophical and linguistic conceptions of performativity, the 1950s gave birth to performative arts of various kinds. Such were, for example, action painting, a term coined by the American critic H. Rosenberg in 1952 to define a specific set of Abstract Expressionist artists who saw the canvas as an "arena in which to act"; or J. Cage's musical happenings, Fluxus' street events, the Darmstadt and Brazilian circles of concrete poetry and the French Situationism which in poetry was represented by I. Isou - all of them originated in the 1950s in various places in the world ${ }^{4}$. Another internationally widespread artistic movement of performative nature was conceptual art.

A few years after the release of Wittgenstein's Philosophical Investigations, the American art critic M. Weitz, who considered himself Neowittgensteinian, proposed a method for distinguishing between art and non-art based on Wittgenstein's concept of "family resemblances". "What can be art and what art can be?" - this question was posed by him by analogy with the language games of the Austrian philosopher of language. According to Weitz, art can be an open concept: "New conditions have constantly arisen and will undoubtedly constantly arise; new art forms, new movements will emerge, which will demand decisions on the part of those interested $<\ldots>$ as to whether the concept should be extended or not" (Weitz 1956: 32). The concept of "art" itself was called into question, which shortly afterwards was transformed into the "art of concepts".

The philosopher and art activist H. Flynt was the first to introduce the

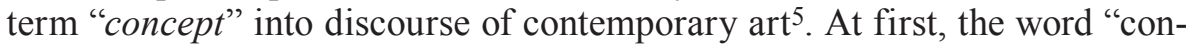
cept" was used in quotation marks as something not yet common in this area.

${ }^{4}$ R. L. Goldberg's book (2001) is a comprehensive overview of performance history.

5 Although the Argentinian-Italian minimalist artist L. Fontana used the term concetto spaziale (spatial concept) in titles of his works as early as in the 1940s. 
The goal of the artist, Flynt argued, was precisely to introduce art to concepts, to bring concepts into action: "“'Concept art" is the first of all an art of which the material is "concepts", as the material of for ex. music is sound. Since "concepts" are closely bound up with language, concept art is a kind of art of which the material is language" (Flynt 1963: http). The purpose of conceptual artists was to make artistic utterances performative, just as the ordinary utterances are according to Wittgenstein and Austin.

Conceptual art became practical philosophy and, in some cases, an acting philosophy of language, as, for example, in the practice of the British group of conceptual artists "Art and Language". The magazine Art-Language became the platform for self-expression for this group in the 1960s. It addressed issues related to the production of art, in an effort to move from "non-linguistic" forms of art, such as painting and sculpture, to theoretical works, to linguistics and pragmatics of the utterance about art itself.

The aim of conceptual artists was to perform concepts, just as the speaker performs speech acts, according to Wittgenstein and Austin. As the American conceptual artist S. Le Witt wrote in his manifesto on Conceptual Art, "in conceptual art the idea or concept is the most important aspect of the work. When an artist uses a conceptual form of art, it means that all of the planning and decisions are made beforehand and the execution is a perfunctory affair. The idea becomes a machine that makes the art" (LeWitt 1967: 80).

It is quite logical that when art started to do with language, language units became constituent elements of works of art. A classic example is the painting by J. Kosuth, "One and Three Chairs" (1965). The canvas shows three representations of a chair altogether: the object itself, its photographical image and the dictionary entry for the word "chair". The value is not attached to one of the three representations of the chair, but to all three elements together:

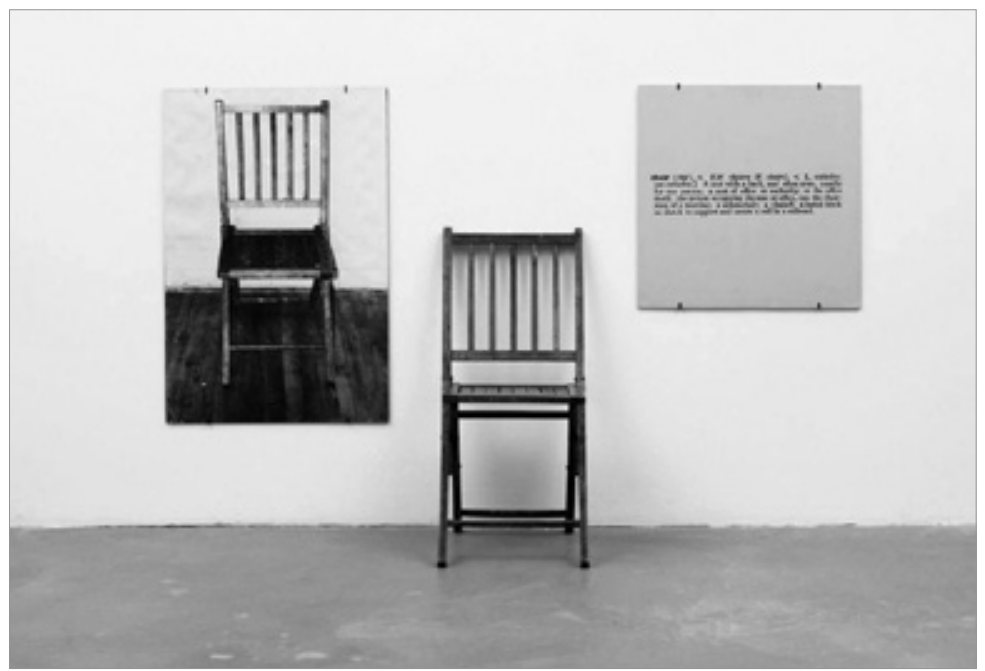


Between 1965 and 2011 Kosuth created a series of neon objects, which were linguistic statements of a conceptual nature. In doing so, the artist put into action the provisions of his own manifesto of 1969 Art after Philosophy which stated that from now on art asks questions about what it is, and language acts as a means of creating new art. In these neon objects, Kosuth explores the nature of the utterance by performativization of the utterance itself, for example, in propositions such as:
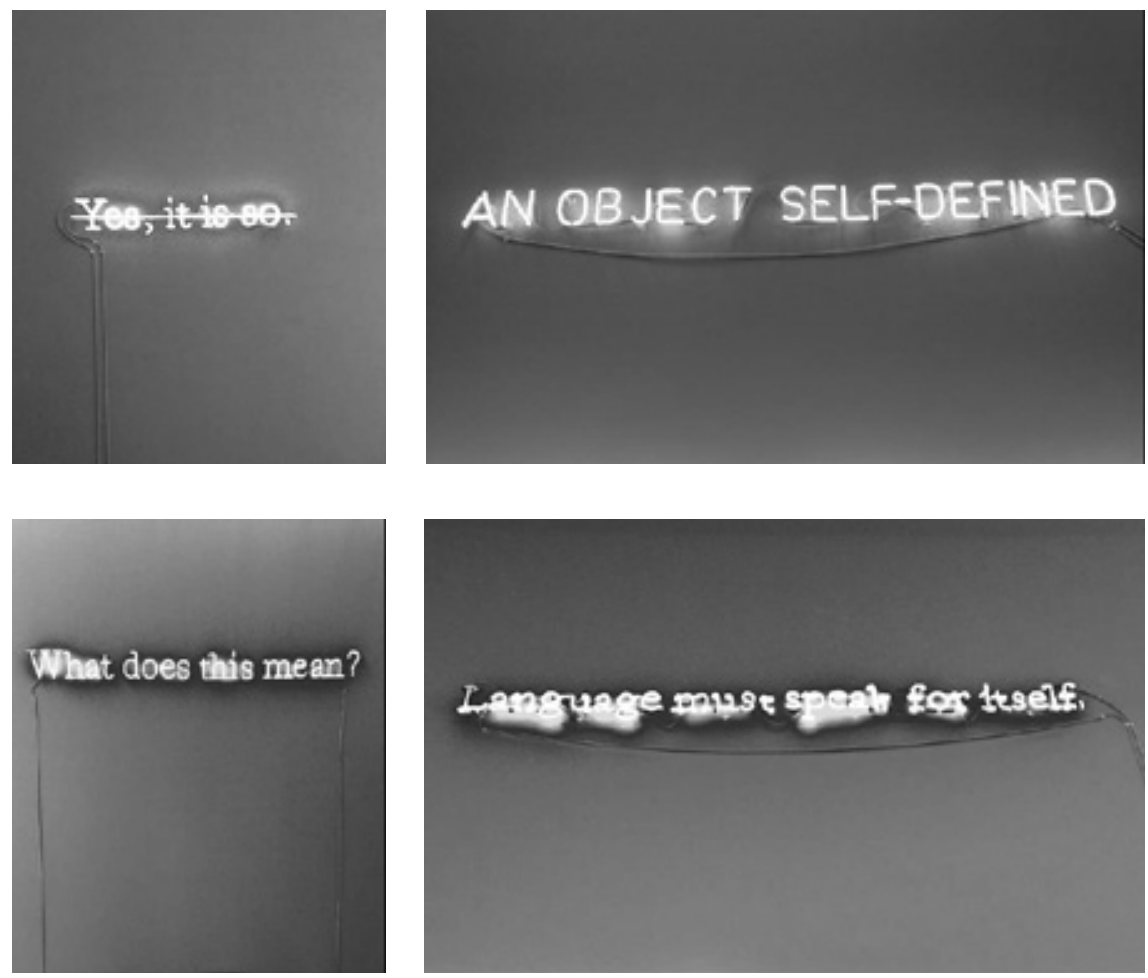

In the Soviet Union and countries of the Eastern bloc, conceptualism manifested itself in the deideologization of the official language of power6. Ordinary utterances invaded the poetic texts and canvases, opposing the official discourse of Soviet authorities. Conceptualism became the most prominent artistic and literary movement over the last five decades in Russia. Moreover, to a greater extent than in the West, literature-centrism and logocentrism have played a significant role in it.

${ }^{6}$ For general accounts of Moscow Conceptualism, see (Бобринская 1994; Groys 2010; Jackson 2010; Rosenfeld 2011). G. Janecek's recent study (2018) provides a comprehensive analysis of Moscow Conceptualist poetry. S. Sasse's book (2003) analyzes the functions of speech acts in conceptualist writings, paintings and actions. 
Already in the first Russian conceptualist paintings and objects, the text almost occupies the leading role. A vivid example of this text-centrism is the work of a Russian conceptualist Artist I. Kabakov titled "The Fly".

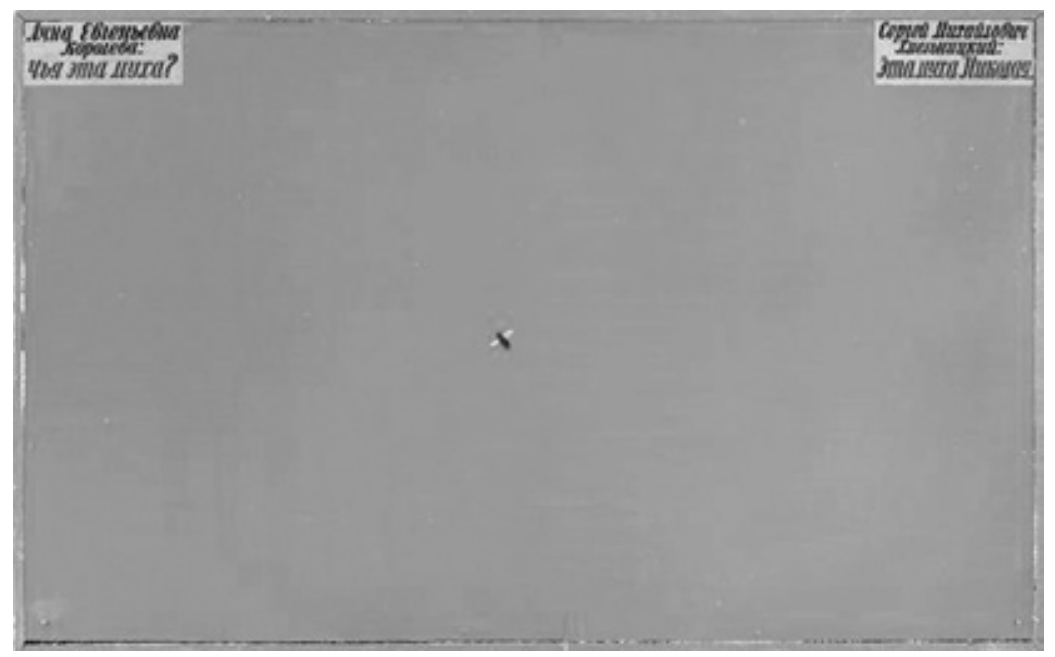

It shows a fly in the center of the canvas and two commentaries by imaginary characters, one of them asking "Whose fly is this?" and the other replying "This is Nikolay's fly". Like in Kosuth's "One and Three Chairs", neither the fly as a material object, nor the dialogue between characters have separate value. They both constitute the concept of the fly as present in the mind of an ordinary Soviet man. Kabakov wrote an essay titled "The Fly as a Subject and Basis for Philosophical Discourse" which he included into the installation "The Fly with Wings"7. We can clearly see in it how the argumentation of a conceptualist artist can be based on an ordinary concept yet producing a discourse of language games reminiscent of that of late Wittgenstein:

"The work presented here, the treatise 'The Fly with Wings' almost visually demonstrates the nature of all philosophical discourse - at its base may lie a simple, uncomplicated and even nonsensical object - an ordinary fly, for example. But yet the very quality of the discourse does not suffer in the least as a result of this. In this very way it is proven (and illustrated) that the idea of philosophizing and its goal consists not at all in the revelation of the original supposition (if this can turn out to be an ordinary fly), but rather in the very process of discourse, in the verbal frivolity itself, in the mutual suppositions of the beginnings and ends, in the flow of connections and representations of that very thing" (cited in Epstein 2010: http).

7 Cf. also with D. Ioffe's study (Иoффe 2017) of the concept of the beetle within the insect code of Kabakov's oeuvre and D. Leiderman's dissertation (2016) containing an analysis of insect concepts in his works. 
As B. Groys, the ideologist of Russian conceptualism, commented on this essay, Kabakov transforms the insignificant word fly into a sort of joker-word which is potentially applicable to anything whatsoever: "Kabakov transforms the word 'fly' into another of these joker-words which are potentially applicable to anything whatsoever...In the ability of an ephemeral word bereft of a noble philosophical tradition to achieve the lofty status of the words which possess this tradition we may see a historic opportunity which is also open to the fly - the opportunity to construct a fly-paradise of its own, its own world of platonic, fly-essences" (Groys 1992: http). Platonism, as we can see, comes forth as a generating paradigm for the conceptual mode of thinking. Concepts occupy the place of Plato's ideas, being transferred into the domain of artistic performance. Groys even goes so far as to identify the whole Russian tradition of thought as conceptual.

In the case of Soviet conceptual art, we may observe an intercultural transfer, where the recipient culture inscribed the extraneous object of transfer into its own intellectual system. It took about a decade for this transfer to happen. It was a contraband transfer though, as official Soviet art would not allow for anything to be imported from the Western world. Yet the term conceptual art illegally filtered its way through Russian dissident artists ${ }^{8}$. B. Groys first used the term in 1979 to refer to a specifically Russian branch of conceptual art, which he called Moscow Romantic Conceptualism. While borrowing the term from Western art, Groys straight away clarifies its limitations in the recipient context. For example, he stresses the mystical nature of the Russian version of Conceptualism, in contrast to allegedly positivist approach in the Western version. Groys embeds the term into the specifically Russian cultural context. Characteristically, he focuses on the literature-centerdness of Russian culture. Mikhail Epstein explains the difference of Russian and Western schools of conceptualism as follows: "In the West, conceptualism substitutes "one thing for another"--a real object for its verbal description. But in Russia the object that should be replaced is simply absent" (Epstein 1995).

This argument was reiterated later by D.A. Prigov, a prominent conceptualist poet and artist. According to Prigov, in Russian culture, the level of object has traditionally been occupied by names of objects (Пригов 1998: http). This principle can be vividly illustrated with Prigov's sketches of installations known as "For the Poor Cleaning Lady" (1990s). This series of paintings displays the figure of the big eye that rises between the curtains in front of a kneeled lady. The rise of the eye is followed by the consequent rise of the word ГЛА 3 that terrifies the poor lady even more than the picture of the eye. The very word makes flesh and substitutes the object it signifies with a still more powerful effect:

8 According to the evidence by artists themselves given in (Альберт 2014). A wider context for the intellectual history of concept art and concept studies is provided in my book (Фещенко 2018). 

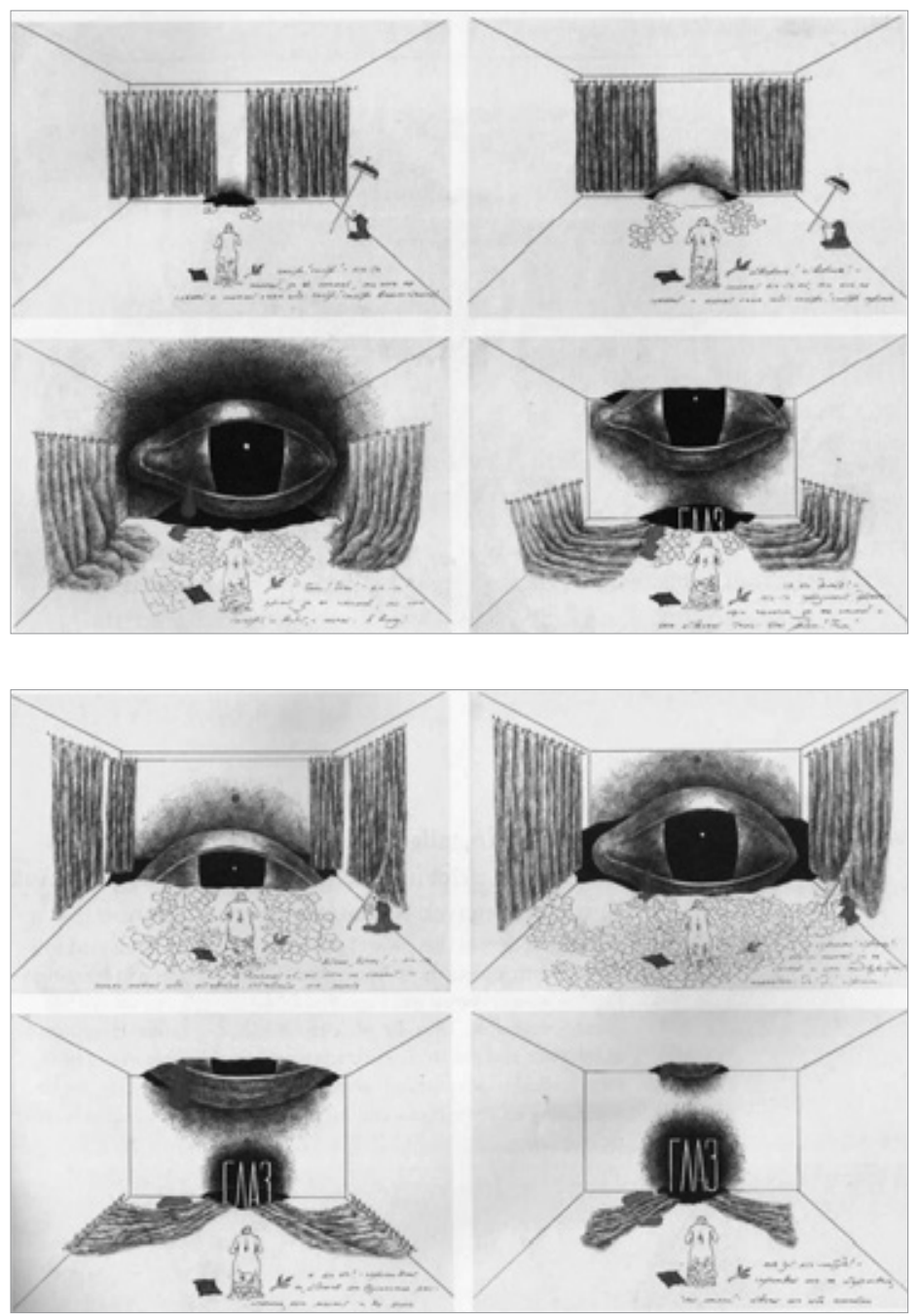

The difference between Russian and Western modes of conceptualist thinking can be seen in these two pictures:

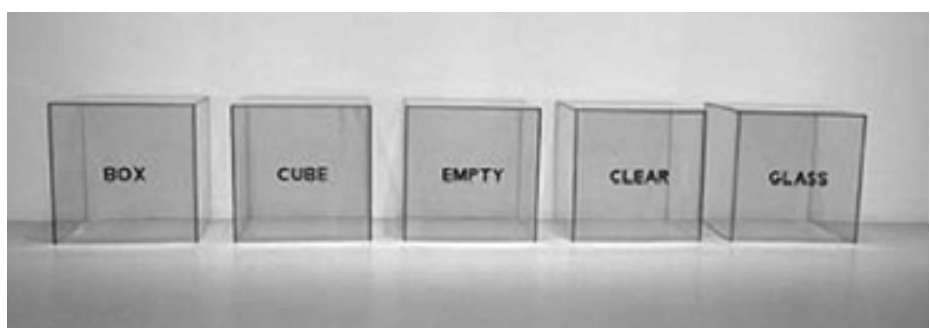




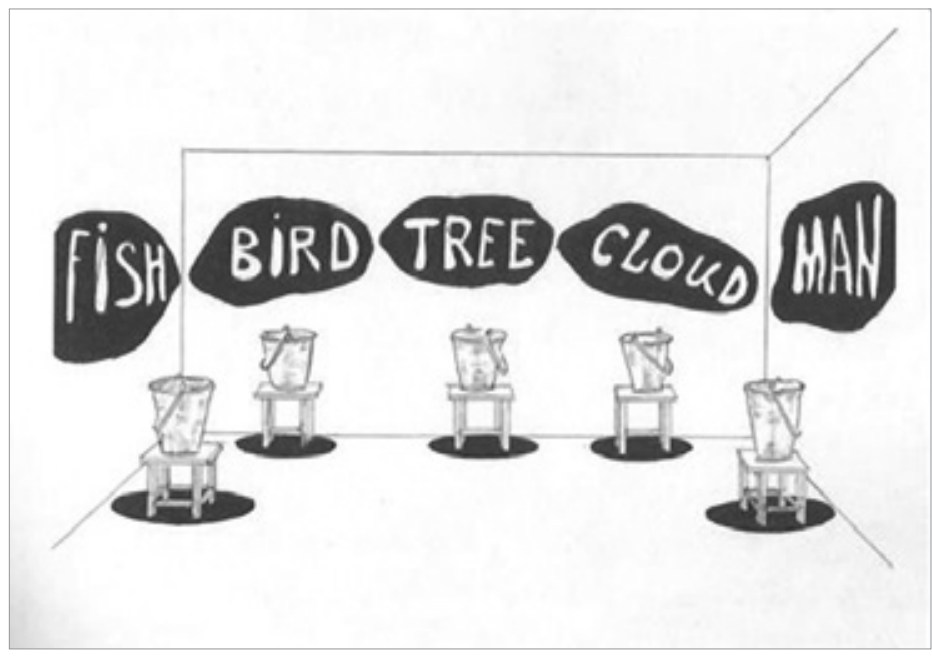

The first, authored by J. Kosuth, reproduces the five boxes marked with attributes: box, cube, empty, clear, glass. These attributes refer to real characteristics of the object: a box is, indeed, a box and a cube which is empty and clear and made of glass. Whereas in the second picture by Prigov, the words fish, bird, tree, cloud and man refer to nothing but themselves. The empty baskets below them act as hollow references. The power of the word in Prigov's version may have no reference to reality.

According to Prigov, in the Western sense, Russian culture has always been quasiconceptual, as it were. Total verbalization of pictorial images, as well as the ubiquitous commentaries accompanying works of art was absolutely in line with Russian tradition of literature. For this reason, Russian conceptualism had a lot more to do with writing texts. Prigov alone produced several thousand poems, let alone a 5-volume collection of his writings recently published in Russia.

In I. Kabakov's visual works, utterances of typical Soviet citizens often constitute the composition of canvases, which, in turn, resemble book sheets or Soviet bureaucratic documents with verse-like verbal structures.
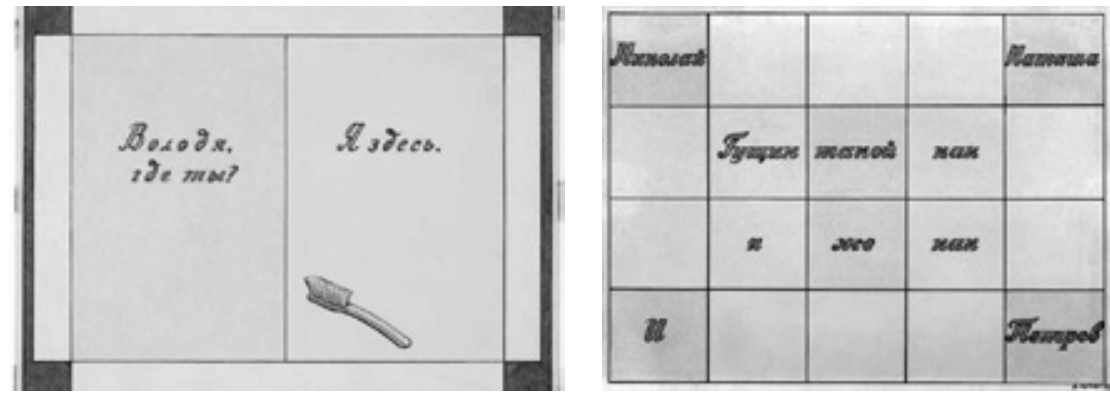
E. Bulatov's paintings represent a kind of visual poetry made of words or their combinations, referring to the reality of the Soviet society.

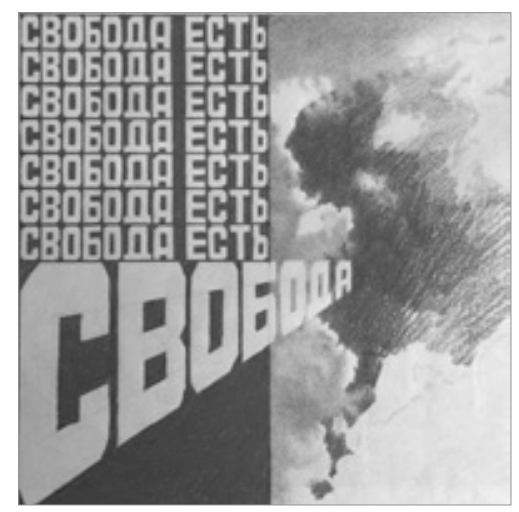

This work by Bulatov is a visual interpretation of Vs. Nekrasov's poem. The repetitive nature of verse lines is typical of this kind of poetry. The poet exploits the contradictory concept of freedom which was used in political discourse of that time as a void signifier. In repeating this signifier several times, the poem reinforces the material texture of the word, producing nothing but pure desemantized rhythm. The only sense the poem makes is that freedom is freedom. Like in every performative, according to Austin and Benveniste, the utterance makes sense only in the act of its statement hic and nunc. The poetic function allows the utterance to multiplicate itself producing the deconstructing artistic effect.

In Russian conceptualist poetry, the reader is faced with fragments of inner or outer speech performed on the page as if on the stage. This principle of staging the ordinary discourse is probably best realized in the poetry of L. Rubinstein. The poetic text here transforms into verbal performance, with utterances sporadically interspersing each other:

1.

Ну что я вам могу сказать?

2.

Он что-то знает, но молчит.

3.

Не знаю, может, ты и прав.

4.

Он и полезней, и вкусней.

5.

У первого вагона в семь.

6.

Там дальше про ученика.

7.

Пойдемте. Я как раз туда. 
8.

Ну что, решили что-нибудь?

9.

Сел - и до самого конца.

10.

Послушай, что я написал.

(Рубинштейн 1996: 47)

A later post-Soviet poem by Rubinstein called Questions of literature is made of utterances pronounced by an unidentified persona:

1.

И вот я пишу...

2.

Я пишу под завыванье ветра, под дребезжанье оконных рам, под шум прибоя...

3.

Я пишу: «Тут началось нечто невообразимое!»

4.

Я пишу под шум прибоя, под приступы тошнотворной тоски, под звон стекла...

5.

Я пишу: «Трудно даже представить себе, что тут началось!»

6.

Я пишу под звон стекла, под насмешливые взгляды окружающих, под завыванье ветра...

7.

Я пишу: «Невозможно и описать, что тут началось!»

8.

Господи! Что началось?

9.

Да и есть ли хоть кто-нибудь, кто сумел бы объяснить, что все это значит?

10.

Если есть, то кто?

11.

Если нет, то почему?

A bit further below in this text, the reader is faced with a set of questions posed either to the reader, or to the author himself, or to the text itself:

99.

И вообще, что все это значит?

100.

И вот мы читаем.

101.

Мы читаем под завыванье ветра, под дребезжанье оконных рам, под шум прибоя...

(idem: 105-113) 
Speech fragments drawn from ordinary speech seem to be forcedly incorporated into the poetic text, as if themselves wondering why. The questions are, it seems, posed to literature as a presumably creative mode of discourse. But nothing creative appears. As B. Groys commented on Rubinstein's work, "performative verbal acts reveal their own elusiveness, or delusiveness, and return us to the text as pure literature, only exposing the desperation and throes of reading" (Гройс 1979: http).

As often in conceptual writings, Russian conceptualist poets make use of found objects or found phrases transformed into concepts as materialized ideas. The objective nature of conceptualist poetic language is exemplified in versograms by D.A. Prigov. Versograms are visual and typographical compositions made entirely of phrases, fragments of Soviet official speeches and songs. Multiplied typographically these verbal objects evidence the absurdity of Soviet reality. Performatives pile up, making the versogram a fractal and recursive verbal apparatus creating an aesthetic object out of humdrum linguistic elements9.

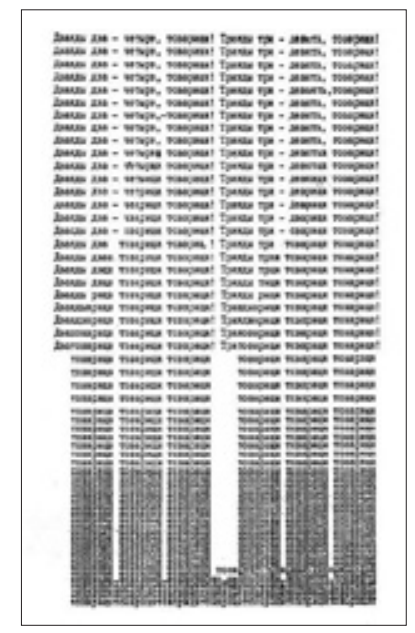

Another Moscow conceptual artist and poet A. Monastyrsky generates mantra-like poetry exploiting minimalist techniques reminiscent of the musical avant-garde. His large poem Poetic World is composed of repetitive six-line refrains with monotone syntactic structures which differ from each other only in minor lexical fillings. In most cases only one word changes in a refrain repeated hundreds of times. Over the course of reading the poem, the reader enters a certain state of mind whereby the increment of sense is reduced to the

9 M. Lipovetsky and I. Kukulin (Липовецкий, Кукулин 2019) argue that “performatism" was Prigov's intentional life-behavioral strategy. P. Arseniev's study (Арсеньев 2019) places Prigov's performativity within the tradition of pragmatic poetics. As my own examples given in this article suggest, performativity was also an essential linguistic principle of bridging word and image within a visual-poetic text. 
minimum. Yet the discourse is still perceived as poetic, although resembling the shamanistic ritual. The refrains are accompanied with performative metacommentaries also taking part of the poem:

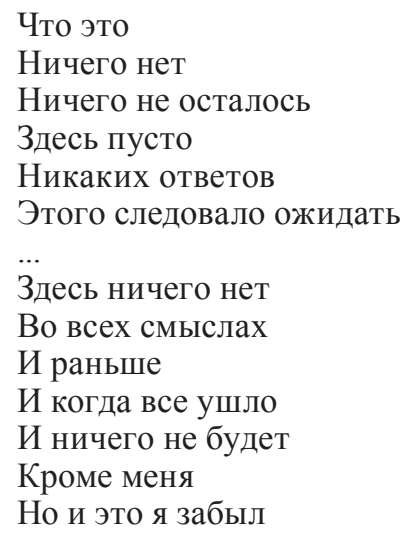

(Монастырский 2007: 69, 89)

The author and the poetic utterance undergo a sort of illocutionary suicide: the all-negative modality denies the existence of any sense. Yet with its very denial it produces a rhythm of presence.

Conceptualist poetry often appears as a set of material objects with no seemingly textual elements. Yet it continues to be deemed poetry. Such is the case of Monastyrsky's work called Elementary poetry - a set of invented objects representing a communicative phenomenon (Finger, Tube etc.) Monastyrsky calls this practice "the poetry of action", in which words give way to pure concepts performing poetic action in the interaction with the user. Monastyrski, himself a linguistic philosopher in a way, shows us how to do words with things.
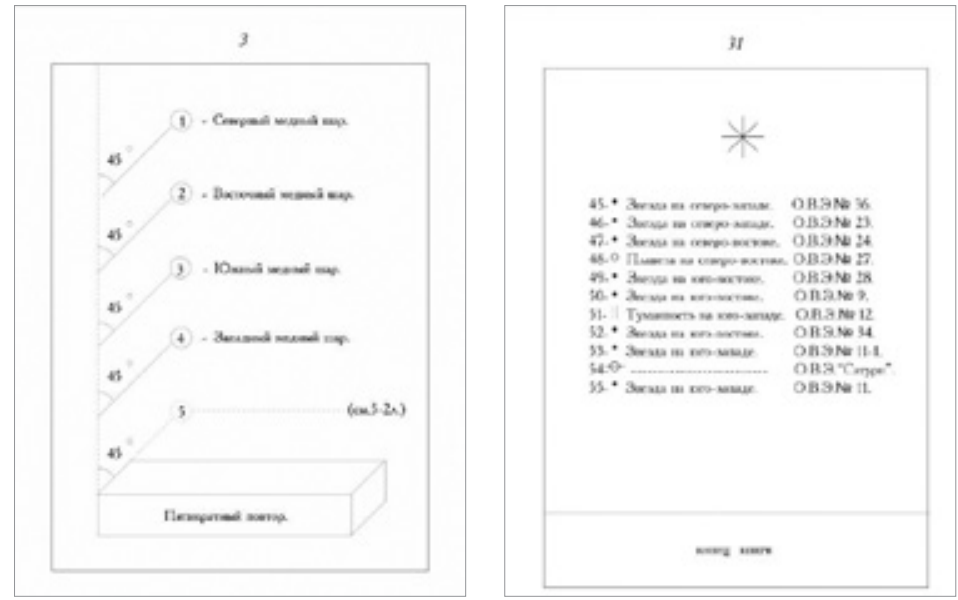

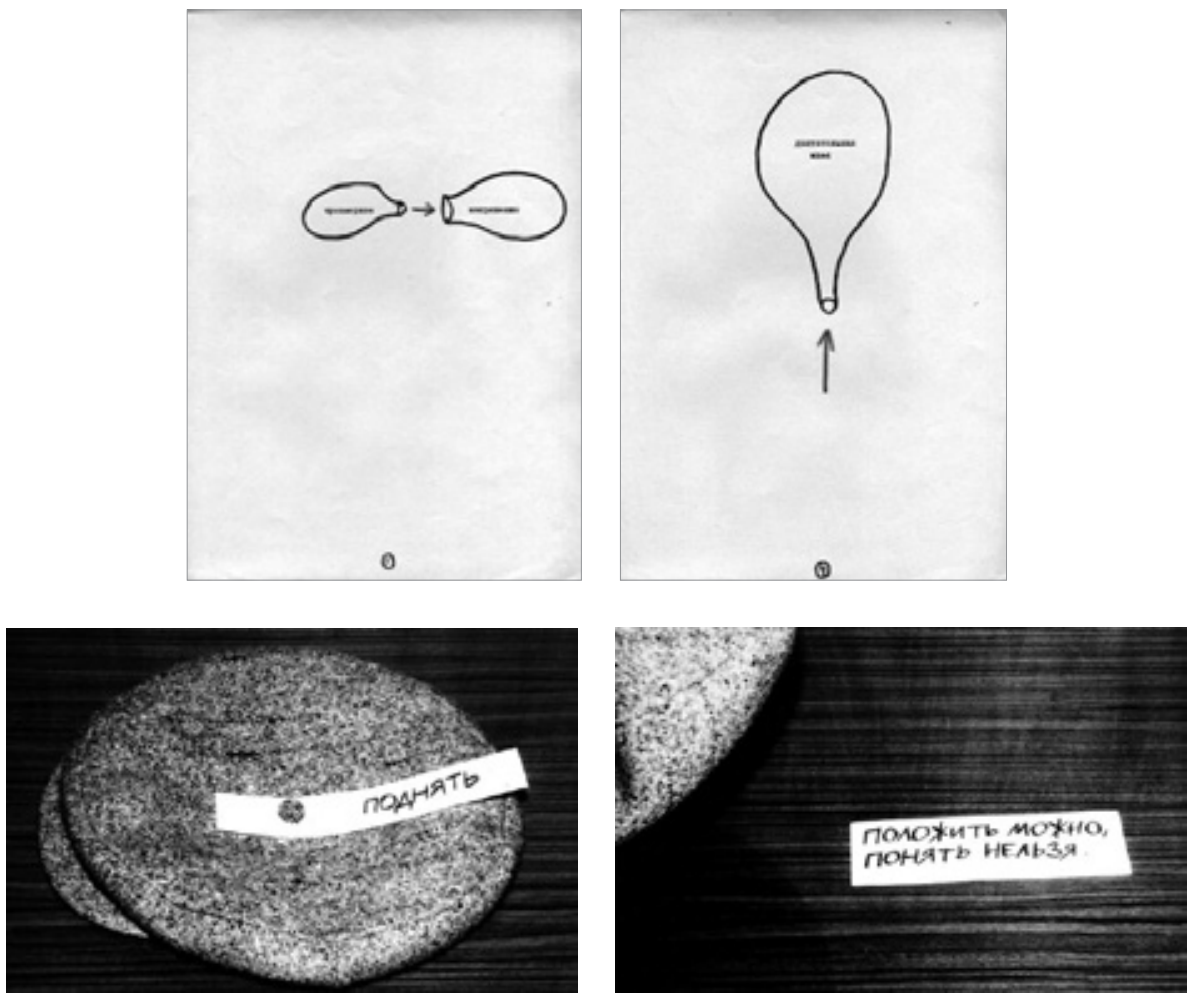

Now, what does that all have to do with creativity? To identify something as creative or not we have to agree what exactly is meant by being creative. According to the dictionaries, the verb create in its basic meaning has two submeanings: 1) to bring into existence out of nothing, without the prior existence of materials or elements used;2) to make or produce from other materials or elements or ideas. In the first case to create means just to produce anything, to generate. It is in this sense that N. Chomsky speaks of linguistic creativity in its generative force. Performance, according to Chomsky, is the act of generation of any linguistic entities. In this sense, anything we do or say is creative. Whereas the second meaning suggests designing or inventing a new form.

The recently released collective scholarly volume titled The Creativity Complex (Beyes, Metelmann 2018) contains contributions challenging the notion of creativity as it is used in contemporary cultures. The authors argue that creativity has become an imperative in nowadays capitalist world. One has to be creative and one has to be considered creative to succeed in any social activity and in the end, to satisfy the need for income. Therefore, the concept of creativity has been devalued. Activities that once used to be the home of creativity, such as art or science, can no longer be thought of as creative, the authors claim. 
If any person has to be creative, then why invent anything new and unheard-of? It seems that the art of conceptualism exactly poses this kind of question. The poetry of Moscow conceptualists devalues the concept of the new and aims at doing away with linguistic creativity. No more word novelties, no more grammatical anomalies, nothing that would produce the effect of the new. The words and phrases are taken from ordinary speech or dictionaries and are performed rather than formed in poems. Performing substitutes creating. Of course, we could say that this kind of poetry is as creative as any other, if we use the first meaning of create. But it is no more linguistically creative, as much as no linguistic creativity is involved in ritual practices. The words are repeated again and again not to generate a new linguistic structure but to perform a ritualistic procedure. This writing procedure is often selfdescribed by its practitioners as an act of "uncreative writing". The American conceptual poet K. Goldsmith argues for this un-creative approach to poetry writing in his book symptomatically called Uncreative Writing: Managing Language in the Digital Age (2011).

Yet I should conclude that, aesthetically, conceptualism is, of course, creative as it makes new aesthetic use of unaesthetic materials. Performance here transforms things into words and concepts, or words and concepts into things, in a unique way only poetry can excel.

\section{REFERENCE LIST}

Austin John. How to Do Things with Words. Oxford: OUP, 1962.

Bauman Richard. Verbal Art as Performance. Prospect Heights, Ill: Waveland Press, 1984.

Beyes Timon, Metelmann Jörg (eds.) The Creativity Complex. A Companion to Contemporary Culture. Bielefeld: Transcript, 2018.

Culler Jonathan. "Philosophy and Literature: The Fortunes of the Performative". Poetics Today 21 (2000): 503-519.

Epstein Mikhail. After the Future. The Paradoxes of Postmodernism \& Contemporary Russian Culture. Amherst: Massachusetts UP, 1995.

Epstein Mikhail. "The Philosophical Implications of Russian Conceptualism". Journal of Eurasian Studies 1 (2010): 64-71. <http://www.sciencedirect.com/science/article/pii/ S1879366509000098\#fn11>. 21.03.20.

Fischer-Lichte Erika. The Transformative Power of Performance: A New Aesthetics. London - New York: Routledge, 2008.

Flynt Henry. "Essay: Concept Art”. La Monte Young (ed.) An Anthology of Chance Operations. N.Y.: L. Young \& J. Mac Low, 1963. <http://www.fondazionebonotto.org/en/collection/ fluxus/flynthenry/11/698.html?from=2449. $>21.03 .20$

Goldberg Roselee. Performance Art: From Futurism to the Present. London - New York: Thames \& Hudson, 2001.

Goldsmith Kenneth. Uncreative Writing: Managing Language in the Digital Age. New York: Columbia UP, 2011.

Groys Boris. We Shall Be Flies (1992)<https://agora8.org/BorisGroys_WeShallBeFlies/> 21.03.20

Groys Boris. History Becomes Form: Moscow Conceptualism. Cambridge, MA: MIT Press, 2010.

Hillis Miller John. Speech Acts in Literature. Stanford: SUP, 2001. 
Jackson Mathew Jesse. The Experimental Group. Ilya Kabakov, Moscow Conceptualism, Soviet Avant-Gardes. Chicago: UCP, 2010.

Janecek Gerald. Everything Has Already Been Written. Moscow Conceptualist Poetry and Performance. Evanston, Ill.: Northwestern UP, 2018.

Laplantine Chloé. Emile Benveniste : poétique de la théorie. Publication et transcription des manuscrits inédits d'une poétique de Baudelaire. P., 2008.

Leiderman Daniil. Moscow Conceptualism and "Shimmering". Princeton: 2016.

LeWitt Sol. "Paragraphs on Conceptual Art". Artforum 10 (1967): 79-83.

Rosenfeld Alla. Moscow Conceptualism in Context. Munich et al.: Prestel, 2011.

Sasse Sylvia. Sprech — und Sprachakte im Moskauer Konzeptualismus. Munchen: Fink, 2003.

Weitz Moritz. "The Role of Theory in Aesthetics". The Journal of Aesthetics and Art Criticism 1 (1956): 27-35.

Альберт Юрий (сост.). Московский кониептуализм. Начало. Нижний Новгород: ГЦСИ, 2014.

Арсеньев Павел. Литература факта высказывания. Очерки по прагматике и материальной истории литературы. СПб.: Транслит, 2019.

Бахманн-Медик Дорис. Культурные повороты. Новые ориентиры в науках о культуре. М.: Новое литературное обозрение, 2017.

Бобринская Екатерина. Концептуализм. М.: Галарт, 1994.

Гройс Борис. «Московский романтический конщептуализм». А-Я 1 (1979): 3-11. <http:// www.mmoma.ru/press/articles/boris_grojs_moskovskij_romanticheskij_konceptualizm> 21.03.20

Иоффе Деннис. «К вопросу о взаимоотношениях текстуального и живописного в поэзии московского концептуализма. (Насекомый Жук Ильи Кабакова: ракурсы демонологии, интертекстуальной иронии и юмора)». Зборник Матице српске за славистику 92 (2017): 273-290.

Липовецкий Марк, Кукулин Илья. «“Искусство предпоследних истин”. Эстетика Д. А. Пригова». Пригов Дмитрий. Мыслли. М.: Новое литературное обозрение, 2019: $6-42$.

Монастырский Андрей. Поэтический мир. М.: Новое литературное обозрение, 1999.

Пригов Дмитрий. «Что надо знать о концептуализме» (1998) <http://azbuka.gif.ru/ important/prigov-kontseptualizm>. 21.03.20.

Рубинштейн Лев. Стихи. СПб.: Издательство Ивана Лимбаха, 1996.

Фещенко Владимир. Литературный авангард на лингвистических поворотах. СПб.: Издательство Европейского университета в Санкт-Петербурге, 2018.

\section{REFERENCE LIST}

Al'bert Iurii (sost.). Moskovskii kontseptualizm. Nachalo. Nizhnii Novgorod: GCSI, 2014.

Arsen'ev Pavel. Literatura fakta vyskazyvaniia. Ocherki po pragmatike i material'noi istorii literatury. SPb.: Translit, 2019.

Austin John. How to Do Things with Words. Oxford: OUP, 1962.

Bakhman-Medik Doris. Kul'turnye povoroty. Novye orientiry v naukakh o kul'ture. M.: Noove literaturnoe obozrenie, 2017.

Bauman Richard. Verbal Art as Performance. Prospect Heights, Ill: Waveland Press, 1984.

Beyes Timon, Metelmann Jörg (eds.) The Creativity Complex. A Companion to Contemporary Culture. Bielefeld: Transcript, 2018.

Bobrinskaia Ekaterina. Kontseptuaizm. M.: Galart, 1994.

Culler Jonathan. "Philosophy and Literature: The Fortunes of the Performative". Poetics Today 21 (2000): 503-519.

Epstein Mikhail. After the Future. The Paradoxes of Postmodernism \& Contemporary Russian Culture. Amherst: Massachusetts UP, 1995. 
Epstein Mikhail. "The Philosophical Implications of Russian Conceptualism". Journal of Eurasian Studies 1 (2010): 64-71. <http://www.sciencedirect.com/science/article/pii/ S1879366509000098\#fn11> . 21.03.20.

Feshchenko Vladimir. Literaturnyj avangard na lingvisticheskikh povorotakh. SPb.: Izdateljstvo Evropeiskogo universiteta v Sankt-Peterburge, 2018.

Fischer-Lichte Erika. The Transformative Power of Performance: A New Aesthetics. London - New York: Routledge, 2008.

Flynt Henry. "Essay: Concept Art". La Monte Young (ed.) An Anthology of Chance Operations. N.Y.: L. Young \& J. Mac Low, 1963. <http://www.fondazionebonotto.org/en/collection/ fluxus/flynthenry/11/698.html?from=2449.> 21.03.20

Goldberg Roselee. Performance Art: From Futurism to the Present. London - New York: Thames \& Hudson, 2001.

Goldsmith Kenneth. Uncreative Writing: Managing Language in the Digital Age. New York: Columbia UP, 2011.

Grois Boris. "Moskovskii romanticheskii konceptualizm". A-IA 1 (1979): 3-11. <http://www. mmoma.ru/press/articles/boris_grojs_moskovskij_romanticheskij_konceptualizm/.> 21.03.20

Groys Boris. We Shall Be Flies (1992) <https://agora8.org/BorisGroys_WeShallBeFlies/> 21.03.20

Groys Boris. History Becomes Form: Moscow Conceptualism. Cambridge, MA: MIT Press, 2010.

Hillis Miller John. Speech Acts in Literature. Stanford: SUP, 2001.

Ioffe Dennis. "K voprosu o vzaimootnosheniiakh tekstual'nogo i zhivopisnogo v poezii moskovskogo kontseptualizma. (Nasekomyi Zhuk Il'i Kabakova: rakursy demonologii, intertekstual'noi ironii i iumora)". Zbornik Matitse srpske za slavistiku 92 (2017): 273290.

Jackson Mathew Jesse. The Experimental Group. Ilya Kabakov, Moscow Conceptualism, Soviet Avant-Gardes. Chicago: UCP, 2010.

Janecek Gerald. Everything Has Already Been Written. Moscow Conceptualist Poetry and Performance. Evanston, Ill.: Northwestern UP, 2018.

Laplantine Chloé. Emile Benveniste : poétique de la théorie. Publication et transcription des manuscrits inédits d'une poétique de Baudelaire. P., 2008.

Leiderman Daniil. Moscow Conceptualism and "Shimmering". Princeton: 2016.

LeWitt Sol. "Paragraphs on Conceptual Art". Artforum 10 (1967): 79-83.

Lipovetskii Mark, Kukulin Il'ia. “'Iskusstvo predposlednikh istin'. Estetika D. A. Prigova”. Monastyrskii Andrei. Poeticheskii mir. M.: Novoe literaturnoe obozrenie, 1999.

Prigov Dmitrii. "Chto nado znat'o kontseptualizme" (1998) <http://azbuka.gif.ru/important/ prigov-kontseptualizm/.>. 21.03.20.

Prigov Dmitrii. Mysli. M.: Novoe literaturnoe obozrenie, 2019: 6-42.

Rosenfeld Alla. Moscow Conceptualism in Context. Munich et al.: Prestel, 2011.

Rubinshtein Lev. Stikhi. SPb.: Izdatel'stvo Ivana Limbakha, 1996.

Sasse Sylvia. Sprech — und Sprachakte im Moskauer Konzeptualismus. Munchen: Fink, 2003.

Weitz Moritz. "The Role of Theory in Aesthetics". The Journal of Aesthetics and Art Criticism 1 (1956): 27-35.

Владимир Фешченко

ПЕРФОРМАТИВНИ ЗАОКРЕТ У ФИЛОСОФИЈИ И ВЕРБАЛНОЈ УМЕТНОСТИ: ЛИНГВИСТИЧКА (НЕ-?) КРЕАТИВНОСТ МОСКОВСКОГ КОНЦЕПТУАЛИЗМА

\section{Резиме}

Перформативни заокрет, који се манифестовао током 1960-их и 1970-их година, пратио је лингвистички заокрет, испољавајући тенденцију ка покретању језика. У раду 
су описане импликације перформативног приступа у области уметничког дискурса односно, дискурса вербалне уметности, а говори се и о московском концептуализму као поетској манифестацији перформативности.

У Совјетском Савезу и земљама источног блока концептуализам се манифестовао кроз деидеологизацију службеног језика власти. Свакодневни искази нашли су се у песничким текстовима и на сликама супротстављајући се званичном дискурсу совјетских власти. Студија вербалних уметничких дела И. Кабакова, Л. Рубинштејна, Д. А. Пригова и А. Манастирског појашњава дијалектику перформативности и (не) креативности у случају вербалних исказа коришћених у песничком дискурсу.

Кључне речи: перформанс, лингвистичка креативност, вербална уметност, московски концептуализам. 